\title{
Характеристика сучасної структури опіоїдів як причини гострих отруєнь (передозувань): у фокусі синтетичні опіоїди
}

\author{
Н.В. Курділь' ${ }^{1}$ О.В. Іващенко² \\ 'Державне підприємство «Науковий центр превентивної токсикології, харчової та хімічної безпеки \\ імені академіка Л.І. Медведя Міністерства охорони здоров'я України», Київ, Україна \\ ²Національний університет охорони здоров'я України імені П.Л. Шупика, Київ, Україна
}

Анотація. Упродовж останніх років у багатьох країнах світу стрімко поширюються нові синтетичні наркотики, ризик смертельного передозування якими вкрай високий. Мета роботи - визначення особливостей сучасної структури наркотичних речовин групи опіоїдів, що найчастіше спричиняють отруєння (передозування), та їх токсичних характеристик. Об'єкт і методи дослідження. Проведено ретроспективний аналіз даних токсикологічного центру Комунального некомерційного підприємства «Київська міська клінічна лікарня швидкої медичної допомоги» щодо результатів дослідження структури наркотичних речовин, які спричинили гострі отруєння (передозування) серед дорослого населення м. Київ у період 1990-2020 рр. Результати. За останні 10 років кількість позитивних тестів, що здійснюються протягом року, на метадон збільшилася у 150, морфін і трамадол —у 100, героїн —у 6 разів, натомість кількість тестів на натуральний опій («ширка») зменшилася у 7 разів. 32017 р. регулярно реєструють випадки отруєння наркотиками, до складу яких входять різні аналоги фентанілу (ацетилфентаніл, бутирилфентаніл, фуранілфентаніл та ін.). Встановлено, що нові синтетичні опіоїди у невеликій кількості додають до складу дизайнерських наркотиків (героїн, «екстазі»), що суттєво підвищує ризик передозування та смерті на вулиці. Висока токсичність нових синтетичних опіоїдів обумовлює необхідність удосконалення протоколів надання медичної допомоги при отруєннях опіоїдами у питаннях застосування антидотів, інтубації трахеї та штучної вентиляції легень на догоспітальному етапі. Висновок. Синтетичні опіоїди являють собою нову тенденцію у сфері дизайнерських наркотиків, а зростання кількості смертельних отруєнь, пов'язаних із їх споживанням, формує нові виклики для лікарів екстреної медичної допомоги та токсикологів.

Ключові слова: гострі отруєння, наркотики, синтетичні опіоїди.

\section{Вступ}

Упродовж останніх років у багатьох країнах світу стрімко поширюються наркотики, що належать до класу нових синтетичних опіоїдів (НСО). У зв'язку з високої активністю і низькою дозою, що необхідна для досягнення бажаних ефектів, ризик передозування цими сполуками та настання смертельного отруєння $є$ вкрай високим.

За даними Європейського моніторингового центру з наркотиків та наркотичної залежності (European Monitoring Centre for Drugs and Drug Addiction - EMCDDA) сучасні синтетичні опіоїди за хімічним складом - аналоги фентанілу або нових нефентанілових сполук. Разом з незаконно виготовленим фентанілом ці препарати в останні роки спричинили зростання смертності від передозування, тоді як показник смертності внаслідок вживання натуральних опіоїдів та тих, що відпускаються за рецептом, залишається відносно стабільним [1].

Центри $з$ моніторингу наркотиків та токсикологічні центри США за останні 10 років неодноразово повідомляли про «кризу опіоїдів», що пов'язана зі стрімким збільшенням кількості випадків передозувань рекреаційними наркотиками серед молоді та швидким розповсюдженням нових представників класу синтетичних опіоїдів, токсичні характеристики яких ще не вивчені $[2,3]$.

Найчастіше синтетичні опіоїди використовують як самостійні продукти, як допоміжні складові героїну або у підроблених ліках, що відпускають за рецептом. Більшість летальних випадків пов'язують з нелегальним застосуванням фентанілу (ацетилфентаніл, бутирилфентаніл, фуранілфентаніл, речовина $\mathrm{U}-47700)[4,5]$.

Представники класу НСО спричиняють класичний опіоїдний токсидром, який можна лікувати за допомогою антидоту налоксону (конкурентного антагоніста опіоїдних $\mu$-рецепторів), однак нерідко необхідні дози антидоту можуть у десятки разів переви- щувати ті, що рекомендовані протоколами лікування опіоїдної коми.

Розповсюдження в Україні опіоїдних наркотиків різних груп та смертельні випадки, що реєструються щороку за даними Державної установи «Центр психічного здоров'я і моніторингу наркотиків та алкоголю Міністерства охорони здоров'я України», оперативні дані Служби безпеки України і Міністерства внутрішніх справ України про обсяги вилучених незаконних наркотиків та прекурсорів для їх виготовлення підтверджують актуальність цієї проблеми.

Мета роботи - визначення особливостей структури наркотичних речовин групи опіоїдів, що найчастіше спричиняють отруєння (передозування), та їх токсичних характеристик.

\section{Об'єкт і методи дослідження}

Об'єкт дослідження: наркотичні речовини групи опію, що спричинили гострі отруєння (передозування) серед дорослого населення м. Київ у період 1990-2020 рр.

Предмет дослідження: токсичні властивості сучасних синтетичних опіоїдів та їх місце у загальній структурі наркотичних отруєнь.

Методи дослідження: проведено ретроспективний аналіз медичних даних пацієнтів з діагнозом «Гостре наркотичне отруєння» (МКХ-10:T40.0-Т40.3), що лікувалися у період 1990-2020 рр. у токсикологічному центрі Комунального некомерційного підприємства (КНП) «Київська міська клінічна лікарня швидкої медичної допомоги»; звіти токсикологічної лабораторії з даними про морфологічну структуру токсичних речовин, що спричинили гострі отруєння (передозування) у період 1990-2020 рр.; дані звітів EMCDDA та наукових публікацій каталогу PubMed з теми дослідження з глибиною пошуку у 15 років.

Статистичний аналіз проведено за допомогою програми «Statistica 12.6» (Windows 10/7). Оцінку достовірності різни- 
ці показників у групах дослідження проводили за допомогою t-критерію Стьюдента з рівнем значущості $\mathrm{p}<0,05$.

Дослідження $\epsilon$ фрагментом науково-дослідної роботи «Наукове обґрунтування безпечності для здоров'я людини пестицидів та агрохімікатів, нових технологій, речовин, матеріалів, виробів, об'єктів довкілля, харчових продуктів та продовольчої сировини; розробка відповідних медичних критеріїв і показників (санітарних та епідеміологічних), санітарно-хімічна, токсиколого-гігієнічна оцінка, регламентація, нормування» (державний реєстраційний номер 0112U001133) на тему «Встановити причинно-наслідкові зв'язки при формуванні сучасних побутових токсикозів та обгрунтувати модифікацію технологій штучної детоксикації організму при соціально значущих отруєннях хімічними речовинами та їх мікстами».

Дослідження виконано відповідно до Гельсінської декларації Всесвітньої медичної асоціації «Етичні принципи медичних досліджень за участю людини у якості об'єкта дослідження» (1964р.) та схвалено комітетом з етики Державного підприємства «Науковий центр превентивної токсикології, харчової та хімічної безпеки імені академіка Л.І. Медведя Міністерства охорони здоров'я України».

\section{Результати}

За даними звіту EMCDDA за 2020 р., синтетичні опіоїди несуть дуже високий ризик отруєння для споживачів (82\% всіх смертей від передозувань) [1]. 32009 р. на європейському ринку наркотиків виявлено $57 \mathrm{HCO}$, включаючи 8, про які вперше повідомлено лише у 2019 р., 2 з яких - похідні фентанілу, решта - іншої хімічної природи, незважаючи на схожість токсичних ефектів [6-8].

Рисунок 1 Структура хімічних речовин групи опіоїдів (натуральні, напівсинтетичні і синтетичні), що виявлені за результатами хіміко-аналітичних досліджень біологічного матеріалу пацієнтів та судово-медичних експертиз у 1990 р.

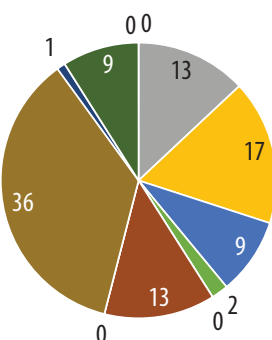

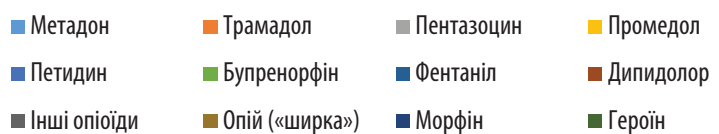

Рисунок 3 Структура хімічних речовин групи опіоїдів (натуральні, напівсинтетичні і синтетичні), що виявлені за результатами хіміко-аналітичних досліджень біологічного матеріалу пацієнтів та судово-медичних експертиз у 2010 p.

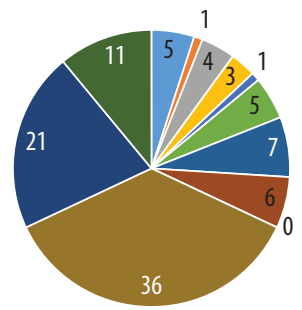

\begin{tabular}{|c|c|c|c|}
\hline петадон & - Трамадол & 口 Пентазоцин & — Промедол \\
\hline - Петидин & - Бупренорфін & — Фентаніл & — Дипидолор \\
\hline - Інші опіоїди & — 0пій («ширка») & - Морфін & — Героїн \\
\hline
\end{tabular}

Небезпека для здоров'я і життя людини, яку створюють синтетичні опіоїди, обумовлена тим, що їх сила дії у тисячі разів перевищує таку «традиційних» вуличних наркотиків. Окреме занепокоєння викликає той факт, що ці речовини все частіше виявляють в різних неін'єкційних формах наркотиків, зокрема у промокальних стрічках (англ. drug blotter) та у рослинних курильних сумішах $[9,10]$.

Перелік наркотичних і психотропних речовин, що стають об'єктом хімічного аналізу, щороку збільшується. Токсикологічна лабораторія КНП «Київська міська клінічна лікарня швидкої медичної допомоги» $\epsilon$ спеціалізованою лабораторією, що працює цілодобово і щороку здійснює десятки тисяч хіміко-аналітичних досліджень біологічного матеріалу (кров, сеча, шлунковий вміст) пацієнтів на наявність токсичних речовин.

Протягом періоду дослідження застосовано різні методи хіміко-аналітичних досліджень: імунохроматографічний аналіз, хроматографія у тонкому шарі сорбенту та газорідинна хроматографія з мас-спектральним детектуванням.

На рис. 1-4 відображена структура хімічних речовин групи опіоїдів (натуральні, напівсинтетичні, синтетичні), що виявлені в біологічному матеріалі пацієнтів, госпіталізованих до токсикологічного центру КНП «Київська міська клінічна лікарня швидкої медичної допомоги» $з$ діагнозом «гостре наркотичне отруєння» (MKX-10:T40.0-T40.3) у період 1990-2020 рр.

Спектр токсичних речовин щороку розширюється та помітно змінюється. Лише за останні 10 років кількість позитивних тестів, що здійснюються протягом року, на вміст метадону збільшилася майже у 150 ( $<<0,001)$, на морфін і трамадол - у 100 ( $<<0,001)$, на героїн - у 6 разів $(p<0,001)$, натомість на натуральний опій («ширка») - зменшилася у 7 разів $(p<0,001)$ (див. рис. 4). Разом 3 тим кількість випадків виявлення у біологічному матеріалі па-

Рисунок 2 Структура хімічних речовин групи опіоїдів (натуральні, напівсинтетичні і синтетичні), що виявлені за результатамихіміко-аналітичних досліджень біологічного матеріалу пацієнтів та судово-медичних експертиз у 2000 p.

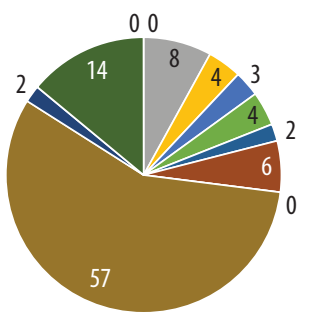

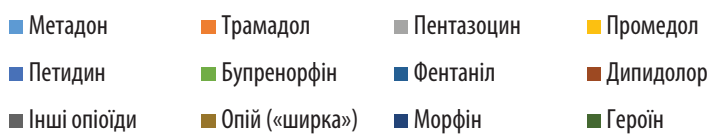

Рисунок 4 Структура хімічних речовин групи опіоїдів (натуральні, напівсинтетичні і синтетичні), що виявлені за результатами хіміко-аналітичних досліджень біологічного матеріалу пацієнтів та судово-медичних експертиз у 2020 p.

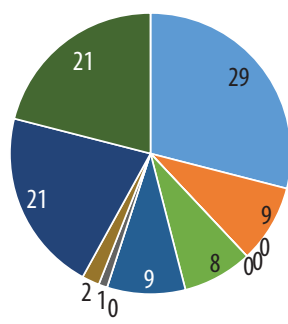

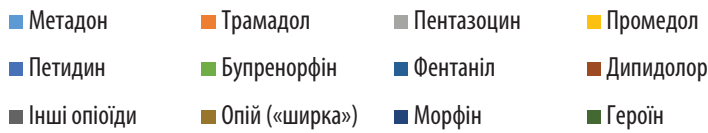


цієнтів продуктів природного опію («ширка») суттєво зменшилася $-357 \%$ у 2000 р. до $2 \%$ у 2020 р.

32017 р. регулярно реєструють випадки отруєння наркотиками, до складу яких входять різні аналоги фентанілу. Встановлено, що НСО у невеликій кількості додають до складу дизайнерських наркотиків (героїн, «екстазі»), що суттєво підвищує ризик передозування та смерті на вулиці. Результати хіміко-аналітичних досліджень таких випадків отримані під час проведення судово-медичних експертиз трупів осіб, що померли внаслідок передозувань (використано метод газорідинної хроматографії з мас-спектральним детектуванням).

Силу дії НСО традиційно порівнюють з такою морфіну і фентанілу. Дійсно, морфін $\epsilon$ агоністом опіоїдних рецепторів та слугує стандартом, з яким порівнюють силу дії всіх інших опіоїдних анальгетиків, зокрема в експериментальних моделях [11].

Фентаніл - рецептурний опіоїдний препарат, який у 50100 разів потужніший, ніж морфін. Його нелегальні форми синтезують у нелегальних лабораторіях і продають через інтернет, як і інші нові психоактивні речовини. До 2015 р. фентаніл був основним синтетичним опіоїдом, з яким стикалися правоохоронні органи, але нещодавно з'явилися аналоги фентанілу та так звані нефентанілові сполуки [12-14].

Сучасні дизайнерські наркотики, що створені на основі опіоїдних речовин, включають не тільки природні, напівсинтетичні та синтетичні похідні алкалоїдів опію, але й синтетичні сурогати та інші речовини подібної до опіоїдів дії, ефекти яких значною мірою блокуються антагоністом $\mu$-опіоїдних рецепторів налоксоном [15-17]. Токсичні ефекти для людини багатьох НСО досі не встановлені.

Ацетилфентаніл (N-феніл-N-[1-(2-фенілетил)-піперидиніл] ацетамід) має вузький терапевтичний індекс із співвідношенням напівлетальної до напівефективної дози $\left(\mathrm{LD}_{50} / \mathrm{ED}_{50}\right)$ у 23 та у 3 рази меншим, ніж у фентанілу та морфіну відповідно. Клінічні показники інтоксикації ацетилфентанілом та клінічні прояви передозування подібні до таких інших опіоїдних анальгетиків [18, 19].

Бутирилфентаніл (N-феніл-N-[1-(2-фенілетил)-4-піперидиніл]бутанамід) виявляє $1 / 8$ ефективності фентанілу і приблизно у 7 разів потужніший, ніж морфін [20].

Фуранілфентаніл (N-феніл-N-[1-(2-фенілетил)-піперидиніл]2-фурамід) виявляє ефективність у дозі 0,02 мг/кг після внутрішньовенного введення мишам [21, 22].

AН-7921 (3,4-дихлор-N\{[1(диметиламіно)циклогексил]метил\} бензамід) виявляє ефект, у 1,7 раза вищий, ніж морфін, провокуючи депресію дихання у мишей $[23,24]$.

U-47700 (3,4-дихлор-N-[(1R,2R)-2-(диметиламіно)-циклогексил]$\mathrm{N}$-метилбензамід), або «U4», в експериментах на мишах проявляє $1 / 10$ ефекту фентанілу, але у 7,5 раза потужніший, ніж морфін, окрім знеболення викликає ейфорію [25-28].

MT-45 (1-циклогексил-4-(1,2-дифенілетил)-піперазин) у 3,5 раза потужніший, ніж морфін, однак має повільний початок дії, викликає ототоксичні ефекти (тривалу глухоту) та глибокий ступінь непритомності, разом з тим має низьку міотичну активність, що може призвести до неправильної діагностики та лікування [29, 30].

Карфентаніл (4-[\{1-оксопропіл\}-феніламіно]-1-[2-фенілетил]4-піперидинкарбонової кислоти метиловий ефір) - аналог фентанілу, ветеринарний анестетик, що застосовують для знеболення у великих тварин, який проявляє у 10 тис. і 100 разів вищий ефект, ніж морфін і фентаніл відповідно [31, 32].

W-18 (4-хлор-N-[\{2Z\}-1-[2-\{4-нітрофеніл\}етил]піперидин-2іліден]бензол-1-сульфонамід), або валерилфентаніл, виявляє у 10 тис. разів вищий ефект, ніж морфін. На сьогодні відсутні дані про характер фармакологічних та токсичних ефектів у людей та тварин, однак вважають, що ця речовина має менш потужну дію, ніж бутирилфентаніл [33, 34].

Діагностика і лікування отруєнь НСО на сучасному етапі $\epsilon$ вкрай складними з огляду на їх величезний токсичний потенціал та недостатні знання про прямі токсичні ефекти для людини та тварин.

Клінічна картина інтоксикації, обумовленої дією усіх вищезазначених речовин, характеризується зниженим рівнем сві- домості, від загальмованості до коми, що нагадує неврологічні ефекти, які виникають за дії класичних опіоїдних агоністів (опій, морфін, героїн та ін.).

Усі синтетичні опіоїди здатні викликати опіоїдний токсидром, для якого характерні: втрата свідомості, міоз, брадикардія, брадипное, ціаноз, гіпотермія. Також клінічними ознаками можуть бути: артеріальна гіпотензія, набряк легень, відсутність перистальтики, нудота, блювання, свербіж шкіри. Зазвичай смерть настає внаслідок апное.

Оскільки багато представників НСО мають хімічну структуру, близьку до фентанілу, а не до морфіну, очікується, що фармакологічні і токсичні властивості цих речовин також будуть більш схожими на такі фентанілу. Таким чином, можна було б передбачити низьку пероральну біодоступність, високу ефективність та коротку тривалість дії, особливо для аналогів фентанілу, однак різні шляхи надходження НСО в організм людини демонструють досить різні клінічні ознаки. Дослідження, що проведені у Швеції із залученням великої кількості спостережень (проєкт Swedish STRIDA), демонструють, що шляхами введення синтетичних наркотиків переважно $є$ : пероральний, сублінгвальний, інтраназальний (вдихання, введення за допомогою назального спрею), інгаляція за допомогою палаючого порошку на алюміні$\epsilon$ єій фользі, інгаляція через випаровувач, ректальне та внутрішньовенне введення [35].

Сучасна діагностика передозування опіоїдів проводиться за такими напрямками: визначення характерних клінічних проявів (токсидром), збір токсикологічного анамнезу, експрес-тестування сечі (імунохроматографічний аналіз) та оцінка ефективності дії налоксону [36].

Основними напрямками лікування токсидрому $\epsilon$ підтримка функції дихання шляхом допоміжної або штучної вентиляції легень, корекція артеріальної гіпотензії за допомогою інфузії кристалоїдів та інотропних засобів (дофамін, епінефрин, адреналін та ін.), зниження токсичного ефекту за допомогою опіоїдного антагоніста налоксону. Більшість осіб з отруєнням (передозуванням) синтетичними опіоїдами потребують інтубації трахеї на догоспітальному етапі.

Роль налоксону в терапії наркотичних отруєнь вкрай важлива. Він $\epsilon$ конкурентним антагоністом $\mu$-опіоїдних рецепторів, що обумовлює його клінічну ефективність при передозуванні опіоїдами. Зазвичай внутрішньовенного введення налоксону буває достатньо для того, щоб вивести постраждалого зі стану коми за лічені секунди. Однак при застосуванні налоксону в екстреній ситуації слід пам'ятати про ускладнення, що можуть бути пов'язані з його дією.

Більшість осіб, що зазнали наркотичного отруєння (передозування), $\epsilon$ активними споживачами наркотиків та мають наркотичну залежність. У таких випадках швидке виведення пацієнта зі стану наркотичної коми може супроводжуватися швидким розвитком синдрому відміни наркотиків. 3 метою запобігання цьому налоксон слід вводити повільно, починаючи з дози 0,2-0,4 мг (0,5-1,0 мл), спостерігаючи за клінічним ефектом. У подальшому слід повторювати його введення у початковій дозі з інтервалом 30-60 хв або частіше (у разі необхідності) до повного пробудження пацієнта (>14 балів за Шкалою коми Глазго).

Слід пам'ятати, що період напіввиведення налоксону значно менший, ніж у більшості опіоїдів. Пацієнти, яким введено налоксон, потребують уважного спостереження і постійного моніторингу вітальних показників протягом декількох годин, навіть після повного пробудження. Повторна хвиля інтоксикації, що настає після припинення дії налоксону, може спричинити повторну втрату свідомості і зупинку дихання, найчастіше це спостерігають при отруєннях метадоном, пентазоцином або левометадилом. Важливо враховувати, що налоксон не має виразної клінічної ефективності у випадках отруєнь (передозувань) бупренорфіном.

У більшості випадків наркотичних отруєнь налоксон $\epsilon$ другорядним засобом лікування, а перевагу надають відновленню і підтримці життєво важливих функцій та проведенню у критичних випадках серцево-легеневої реанімації. 
Початкова доза налоксону зазвичай сягає 0,4-2 мг, у випадках із НСО може бути потрібна доза 10-20 мг [37].

Дані відділень невідкладної медичної допомоги у США свідчать, що стандартні дози налоксону ефективні лише у $15 \%$ випадків отруєнь НCO, а середня доза налоксону досягає 3,36 мг. Також автори вказують, що налоксон у високих початкових дозах (>2 мг) спричиняє розвиток синдрому відміни з усіма негативними наслідками (збудження, судоми, набряк легень, набряк мозку, зупинка серця) [38]. Сьогодні триває пошук найбільш ефективних форм налоксону для застосування у випадках отруєння синтетичними аналогами фентанілу. Так, у США та країнах Європейського Союзу для екстреного застосування поза межами лікарні доступні дві форми налоксону: автоматичний інжектор для внутрішньом'язового введення (2 та 0,4 мг) та назальний спрей (4 Mr).

Зауважимо, що всі попередні дослідження ефективності вищезазначених засобів доставки антидотів проводили на моделі з героїном, тому їх не можна автоматично рекомендувати для застосування у випадках отруєнь (передозувань) НСО. Разом з тим результати досліджень підтвердили однакову ефективність двох шляхів введення налоксону та їх клінічну ефективність на догоспітальному етапі [39].

\section{Обговорення}

НСО спричинили тисячі смертей за останні 2 роки і ця кількість, ймовірно, $є$ заниженою. Так, у США за останні 2 роки кількість смертей лише від порушення правил застосування метадону перевищила 15 тис. Однак загалом показники смертності від отруєнь природними та напівсинтетичними опіоїдами за останні роки стабілізувалися, натомість смертність від синтетичних опіоїдів зростає з тривожною швидкістю [40]. Стрімке поширення синтетичних опіоїдів невідомого походження та з невизначеною токсичністю зумовлює актуальність перегляду наявних підходів до застосування налоксону, як на догоспітальному етапі, так i в умовах стаціонару.

Деякі НСО, наприклад МТ-45, мають унікальні властивості, такі як двостороння втрата слуху та відсутність міозу. Речовина U-47700 діє короткочасно, викликає наркотичний синдром і виразну ейфорію і формує сильне бажання у споживачів повторного застосування.

Жодних протокольних токсикологічних досліджень і контрольованих клінічних досліджень з вивчення токсичності і фармакологічних характеристик більшості НСО не проводили, існують лише поодинокі дослідження на тваринах та з використанням методів in vitro або моделювання. Очевидно, що необхідні більш фундаментальні дослідження з фармакології та токсикології цих сполук, окремі з яких мають статус лише хімічних речовин, офіційно не є ліками, наркотиками або їх прекурсорами.

Справжні масштаби зловживання синтетичними наркотиками складно визначити. У більшості випадків діагноз встановлюють на основі позитивної реакції на введення налоксону, але підтверджувальне експрес-тестування не проводять. У разі смерті внаслідок передозування фентанілу при більш детальному хіміко-аналітичному дослідженні у $17 \%$ померлих у біологічному матеріалі виявляли його різні аналоги, що потенційно могли спричинити летальний наслідок [41]. Результати багатьох досліджень підтверджують необхідність посилення спроможності хімікоаналітичних лабораторій токсикологічних центрів і судово-медичних токсикологічних лабораторій у виявленні НСО з метою визначення конкретної ролі нових речовин у зростаючій епідемії передозування [42].

Сьогодні синтетичні опіоїди - це хімічні сполуки, що діють, як агоністи опіоїдних рецепторів, до яких належать різні аналоги фентанілу (ацетилфентаніл, акрилоїлфентаніл, карфентаніл, фуранілфентаніл, 4-фторбутірилфентаніл, окфентаніл). Нещодавно з'явилися нефентанілові сполуки з різними хімічними структурами, такі як АН-7921, МТ-45 і U-47700 та ін. Враховуючи те, що за останні 10 років стрімко збільшується кількість публікацій про випадки смертельних отруєнь, пов'язаних із вживанням синтетичних опіоїдів у США та країнах Європейського Союзу, виявлення цих сполук у біологічних зразках має вирішальне значення для розуміння їх концентрації і розподілу в рідинах організму.

Значна частка синтетичних опіоїдів $\epsilon$ похідними одного фармакологічного засобу - фентанілу. Однак багато інших сполук (наприклад АН-7921, МТ-45, U-47700) мають відмінну хімічну структуру. Усі ці речовини достатньо вільно поширюються для продажу, переважно як «дослідні хімікати» через інтернет-магазини, і використовуються в якості замінників контрольованих опіоїдів (метадону, бупренорфіну), але на нелегальному ринку наркотиків вони також продаються, як «героїн» для необізнаних споживачів, що обумовлює високий ризик отруєнь.

Швидке поширення цих речовин обумовлене в тому числі їх невизначеним правовим статусом: вони не $\epsilon$ ліками, відсутні в переліках наркотичних речовин, поки ще відсутні офіційні стандартизовані методики їх виявлення; вони відносно легко доступні для придбання; мають відносно низьку вартість; потребують складних методів для виявлення в біологічних матеріалах людини.

Доведено, що НСО у невеликій кількості додають до складу дизайнерських наркотиків («екстазі», героїн, нелегальний метадон), що суттєво підвищує ризик передозування та смерті на вулиці. НСО створюють надзвичайні проблеми для регуляторних та правоохоронних органів, однак частина їх вже поповнили контрольні списки $[43,44]$.

Сьогодні фентаніл та його аналоги зазвичай не використовують самостійно, їх змішують з героїном та іншими дизайнерськими наркотиками, а потім реалізують серед споживачів наркотиків, як продукт героїну.

Таким чином, роль аналогів фентанілу у випадках смерті від передозування (наприклад метадоном або героїном) може бути недооцінена. Справжня кількість смертей, пов'язаних із синтетичними опіоїдами, може бути набагато вищою, ніж зазначено в офіційних звітах, оскільки більшість токсикологічних та судово-медичних лабораторій не проводять аналіз на наявність фентанілу або НСО, якщо для цього немає конкретних підстав.

\section{Висновок}

Вживання синтетичних опіоїдів $\epsilon$ новою тенденцією у сфері рекреаційних наркотиків, а зростання кількості смертельних отруєнь, пов'язаних із їх стихійним споживанням у багатьох країнах світу, свідчить про те, що поширення таких речовин серед молоді $\epsilon$ медико-соціальною проблемою глобального рівня.

Нелегальне розповсюдження метадону та $\mathrm{HCO} \in$ значною загрозою для здоров'я населення, оскільки існує великий попит на них серед молоді. За таких обставин слід нарощувати потенціал екстреної медичної та токсикологічної допомоги, а саме: підтримувати інформування медиків, оновлювати підходи до застосування антидотів, впроваджувати нові методи і методики хіміко-аналітичних досліджень 3 ідентифікації нових синтетичних наркотиків, їх метаболітів та біомаркерів.

\section{Подяка}

Автори висловлюють подяку адміністрації КНП «Київська міська клінічна лікарня швидкої медичної допомоги» в особі заступника головного лікаря з медичної частини О.В. Берегового і колективу токсикологічної лабораторії в особі завідувача Л.Т. Лукашевич за сприяння у проведенні досліджень та отриманні статистичних даних.

\section{Перспективи подальших досліджень}

НСО являють собою нову тенденцію у сфері рекреаційних наркотиків та представлені широким спектром хімічних речовин, токсичні властивості яких досі невідомі. Особливості формування токсичних ефектів та клінічних синдромів, підходи до застосування антидотів, методи лабораторної ідентифікації нових наркотичних речовин та їх біомаркерів $\epsilon$ окремими перспективними напрямками подальших наукових досліджень.

\section{Персональний внесок кожного}

\section{3 авторів у підготовку статті}

Н.В. Курділь: огляд літератури, переклад англомовних джерел, статистична обробка результатів дослідження, формулювання розділів «Об'єкт і методи дослідження», «Результати». 
О.В. Іващенко: узагальнення результатів дослідження, формулювання розділів «Вступ», «Обговорення», «Заключення», оформлення статті для подачі до редакції журналу.

Конфлікт інтересів: відсутній.

Conflict of interests: the authors declare no conflict of interests.

Список використаної літератури/References:

1. EMCDDA (2020) Looking back on 25 years of annual reporting on the drugs problem in Europe (https://www.emcdda.europa.eu/publications/brochures/25-years-annual-reporting_en).

2. EMCDDA (2020) European Drug Report 2020: Trends and Developments (https://www.hareact.eu/ru/node/6080).

3. EMCDDA (2015) Drug profiles (http://www.emcdda.europa.eu/drug-profiles).

4. Wilson N., Kariisa M., Seth P. et al. (2020) Drug and Opioid-Involved Overdose Deaths United States, 2017-2018. MMWR Morb. Mortal. Wkly Rep., 69(11):290-297. doi:10.15585/ mmwr.mm6911a4.

5. Tori M.E., Larochelle M.R., Naimi T.S. (2020) Alcohol or Benzodiazepine Co-involvement With Opioid Overdose Deaths in the United States, 1999-2017.JAMA Network Open, 3(4): e202361. doi:10.1001/jamanetworkopen.2020.2361.

6. Beardsley P.M., Zhang Y. (2018) Synthetic Opioids. Handb. Exp. Pharmacol., 252: 353-381. doi: 10.1007/164_2018_149.

7. Clark D.J., Schumacher M.A. (2017) America's Opioid Epidemic: Supply and Demand Considerations. Anesth. Analg., 125(5): 1667-1674. doi: 10.1213/ANE.0000000000002388.

8. Prekupec M.P, Mansky P.A, Baumann M.H. (2017) Misuse of Novel Synthetic Opioids: A Deadly New Trend. J. Addict. Med., 11(4):256-265. doi: 10.1097/ADM.0000000000000324.

9. Barbosa L.M., Santos J.M., de Morais D.R. et al. (2019) Fast UHPLC-MS/MS method for analysis of furanylfentanyl in different seized blotter papers. Drug Test Anal., 11(1): 178-183. doi: 10.1002/dta.2472.

10. Concheiro M., Chesser R., Pardi J. et al. (2018) Postmortem Toxicology of New Synthetic Opioids. Front. Pharmacol., 9: 1210. doi: 10.3389/fphar.2018.01210.

11. Pasternak G.W., Pan Y.X. (2013) Mu opioids and their receptors: evolution of a concept. Pharmacol Rev. , 65(4): 1257-317. doi: 10.1124/pr.112.007138.

12. Armenian P., Vo K.T., Barr-Walker J. et al. (2018) Fentanyl, fentanyl analogs and novel synthetic opioids: A comprehensive review. Neuropharmacology, 134(Pt A): 121-132. doi: 10.1016/..neuropharm.2017.10.016.

13. Fornili K.S. (2019) International Control Efforts to Curb the Global Production and Trafficking of Fentanyl and Other Synthetic Opioids. J. Addict. Nurs., 30(1): 71-76. doi: 10.1097/ JAN.0000000000000269.

14. Pichini S., Solimini R., Berretta P. et al. (2018) Acute Intoxications and Fatalities From Illicit Fentanyl and Analogues: An Update. Ther. Drug Monit., 40(1): 38-51. doi: 10.1097/ FTD.0000000000000465.

15. Acuna V.S., Abels E.M., Alhelwani A. et al. (2020) Treating Non-fentanyl-derived Synthetic Opioid. Overdose with a Traditional Opioid Reversal Agent. Cureus, 12(3): e7241. doi: 10.7759/cureus.7241.

16. Kim H.K., Nelson L.S. (2015) Reducing the harm of opioid overdose with the safe use of naloxone: a pharmacologic review. Expert. Opin. Drug Saf., 14: 1137-1146. doi: 10.1517/14740338.2015.1037274.

17. Traynor K. (2016) Experts weigh minimum naloxone dose as opioid crisis evolves. Am. J. Health Syst. Pharm., 73: 1892-1894. doi:10.2146/news160067.

18. Wilde M., Pichini S., Pacifici R.et al. (2019) Metabolic Pathways and Potencies of New Fentanyl Analogs. Front. Pharmacol., 10: 238.doi: 10.3389/fphar.2019.00238.

19. Rogers J.S., Rehrer S.J., Hoot N.R. (2016) Acetylfentanyl: an emerging drug of abuse. J. Emerg. Med., 50: 433-436. doi: 10.1016/j.jemermed.2015.10.014.

20. Poklis J., Poklis A., Wolf C. et al. (2016) Two fatal intoxications involving butyryl fentanyl. J. Anal. Toxicol., 40: 703-708. doi:10.1093/jat/bkw048.

21. Hendrickson R.G., Akpunonu P., Hughes A.R. et al. (2019) Highly potent fentanyl analogs: apnea from exposure to small quantities of ss-hydroxyfentanyl and furanylfentanyl. Clin. Toxicol. (Phila), 57(9): 813-815. doi: 10.1080/15563650.2018.1558233.

22. Guerrieri D., Rapp E., Roman M. et al. (2017) Postmortem and Toxicological Findings in a Series of Furanylfentanyl-Related Deaths. J. Anal. Toxicol., 41(3): 242-249. doi: 10.1093/jat/bkw129.

23. Rambaran K.A., Amin Z.M., Fleming S.W. et al. (2018) AH-7921: A review of previously published reports. Proc. (Bayl. Univ. Med. Cent.), 31(3): 303-306. doi: 10.1080/08998280.2018.1465320.

24. Katselou M., Papoutsis I., Nikolaou P et al. (2015) AH-7921: the list of new psychoactive opioids is expanded. Forensic Toxicol., 33(2): 195-201. doi: 10.1007/s11419-015-0271-z.

25. Armenian P., Olson A., Anaya A. etal. (2017) Fentanyl and a novel synthetic opioid U47700 masquerading as street «Norco» in Central California: a case report. Ann. Emerg. Med., 69: 87-90. doi: 10.1016/j.annemergmed.2016.06.014.
26. Ruan X., Chiravuri S., Kaye A.D. (2016) Comparing fatal cases involving U-47700. Forensic Sci. Med. Pathol., 12: 369-371. https://link.springer.com/article/10.1007/s12024-016-9795-8.

27. Elliott S.P., Brandt S.D., Smith C. (2016) The first reported fatality associated with the synthetic opioid 3,4-dichloro-N-[2-(dimethylamino)cyclohexyl]-N-methylbenzamide (U-47700) and implications for forensic analysis. Drug Test. Anal., 8: 875-879. doi: 10.1002/dta.1984.

28. Schneir A., Metushi l.G., Sloane C. et al. (2017) Near death from a novel synthetic opioid labeled U-47700: emergence of a new opioid class. Clin. Toxicol. (Phila), 55: 51-54. doi: 10.1080/15563650.2016.1209764.

29. Siddiqi S., Verney C., Dargan P. et al. (2015) Understanding the availability, prevalence of use, desired effects, acute toxicity and dependence potential of the novel opioid MT-45. Clin. Toxicol. (Phila), 53: 54-59. doi:10.3109/15563650.2014.983239.

30. Helander A., Backberg M., Beck 0. (2014) MT-45, a new psychoactive substance associated with hearing loss and unconsciousness. Clin. Toxicol. (Phila), 52: 901-904. doi:10.3109/155 63650.2014.943908.

31. Green T.C., Gilbert M. (2016) Counterfeit medications and fentanyl. JAMA Intern. Med., 176: 1555-1557. doi:10.1001/jamainternmed.2016.4310.

32. Leen J.L.S., Juurlink D.N. (2019) Carfentanil: a narrative review of its pharmacology and public health concerns. Can. J. Anaesth., 66(4): 414-421. doi: 10.1007/s12630-019-01294-y.

33. Huang X.P., Che T., Mangano T.J. et al. (2017) Fentanyl-related designer drugs W-18 and W-15 lack appreciable opioid activity in vitro and in vivo. JCI Insight, 2(22): e97222. doi: 10.1172/ji.i.nsight.97222.

34. AlzghariS.K., Amin Z.M., Chau S. et al. (2017) On the Horizon: The Synthetic Opioid U-49900. Cureus, 9(9): e1679. doi: 10.7759/cureus.1679.

35. Helander A., Bäckberg M., Hultén P. et al. (2014) Detection of new psychoactive substance use among emergency room patients: Results from the Swedish STRIDA project. Forensic. Sci. Internat., 243: 23-29. doi:10.1016/j.forsciint.2014.02.022.

36. Zuckerman M., Weisberg S.N., Boyer E.W. (2014) Pitfalls of intranasal naloxone. Prehosp. Emerg. Care, 18: 550-554. doi:10.3109/10903127.2014.896961.

37. Kim H.K., Nelson L.S. (2015) Reducing the harm of opioid overdose with the safe use of naloxone: a pharmacologic review. Expert. Opin. Drug Saf., 14(7): 1137-46. doi: 10.1517/14740338.2015.1037274.

38. Schumann H., Erickson T., Thompson T.M. et al. (2008) Fentanyl epidemic in Chicago, Illinois and surrounding Cook County Clin Toxicol (Phila), 6(6): 501-506. doi: 10.1080/15563650701877374.

39. Abdulrahim D., Bowden-Jones 0.; NEPTUNE group (2018) The misuse of synthetic opioids: harms and clinical management of fentanyl, fentanyl analogues and other novel synthetic opioids. Information for clinicians (https://www.emcdda.europa.eu/best-practice/evidencesummaries/naloxone-revert-synthetic-opioids-overdose_en).

40. Rudd R.A., Seth P., David F. et al. (2016) Increases in drug and opioid-involved overdose deaths - United States, 2010-2015. MMWR Morb. Mortal. Wkly Rep., 65: 1445-1452. doi: 10.15585/mmwr.mm655051e1.

41. Peterson A.B., Gladden R.M., Delcher C. et al. (2016) Increases in Fentanyl-Related Overdose Deaths - Florida and Ohio, 2013-2015. MMWR Morb. Mortal. Wkly Rep., 65:844-849. doi: http://dx.doi.org/10.15585/mmwr.mm6536a9.

42. United Nations Office on Drugs and Crime (2017) Global Synthetic Drugs Assessment (http:// www.unodc.org/documents/scientific/Global_Drugs_Assessment_2017.pdf).

43. Drug Enforcement Administration (2018) Schedules of Controlled Substances: Temporary Placement of Fentanyl-Related Substances in Schedule I (https://www.federalregister.gov/ documents/2018/02/06/2018-02319/schedules-of-controlled-substances-temporaryplacement-of-fentanyl-related-substances-in-schedule-i).

44. Armenian P., Vo K.T., Barr-Walker J.et al. (2018) Fentanyl, fentanyl analogs and novel synthetic opioids: A comprehensive review. Neuropharmacology, 134: 121-132. doi: 10.1016/j. neuropharm.2017.10.016.

\section{The characteristics of the modern} structure of opioids as causes of acute poisoning (overdose): in focus the synthetic opioids

\section{N.V. Kurdil', O.V. Ivashchenko²}

'State Enterprise «Research Center of Preventive Toxicology, Food and Chemical Safety named after Academician L.I. Medved of the Ministry of Health of Ukraine», Kyiv, Ukraine ${ }^{2}$ Shupyk National Healthcare University of Ukraine, Kyiv, Ukraine

Abstract. In recent years, new synthetic drugs have spread rapidly in many parts of the world, and the risks of fatal overdoses are 
extremely high. The aim is to determine the features of the modern structure of narcotic drugs of the opioid group, which most often cause poisoning (overdose), and their toxic characteristics. Material and methods. A retrospective analysis of the data of the Toxicological Center of the Municipal Non-Commercial Enterprise "Kyiv City Clinical Ambulance Hospital» on the results of monitoring the structure of narcotic substances that caused acute poisoning (overdose) among the adult population of Kyiv in 1990-2020. Results. Over the past 10 years, the number of positive tests performed during the year for methadone has increased 150, morphine and tramadol -100 , heroin -6 times; instead, the number of tests for natural opium («shirka») decreased by 7 times. Since 2017, cases of drug poisoning, which include various fentanyl analogues (acetylfentanyl, butyrylfentanyl, furanylfentanyl, etc.), have been regularly registered. It has been found that small amounts of new synthetic opioids are added to designer drugs (heroin, "ecstasy"), significantly increasing the risk of overdose and death on the street. The high toxicity of new synthetic opioids necessitates the improvement of existing protocols for the provision of medical care for opioid poisoning in the use of antidotes, tracheal intubation and pulmonary ventilation in the prehospital stage. Conclusion. Synthetic opioids are a new trend in the field of designer drugs, and the growing number of fatal poisonings associated with their use is creating new challenges for emergency physicians and toxicologists.

Key words: acute poisoning, drugs, synthetic opioids.

\section{Відомості про авторів:}

Курділь Наталія Віталіївна - кандидат медичних наук, старший науковий співробітник Державного підприємства «Науковий центр превентивної токсикології, харчової та хімічної безпеки імені академіка Л.I. Медведя Міністерства охорони здоров'я України», Київ, Україна. ORCID ID: 0000-0001-7726-503X

Іващенко Олег Васильович — кандидат медичних наук, доцент кафедри медицини невідкладних станів Національного університету охорони здоров'я України імені П.Л. Шупика, Київ, Україна. ORCID ID: 0000-0003-2866-707X

\section{Адреса для листування:}

Курділь Наталія Василівна

03680, Київ, вул. Героїв оборони, 6

E-mail: kurdil_nv@ukr.net

\section{Information about the authors:}

Kurdil Natalia V. - Candidate of Medical Sciences, Senior Researcher of the State Enterprise «Research Center of Preventive Toxicology, Food and Chemical Safety named after Academician L.I. Medved of the Ministry of Health of Ukraine», Kyiv, Ukraine. ORCID ID: 0000-00017726-503X

Ivashchenko Oleg V. - Candidate of Medical Sciences, Associate Professor of the Department of Emergency Medicine of the Shupyk National Healthcare University of Ukraine, Kyiv, Ukraine. ORCID ID: 0000-0003-2866-707X

\section{Address for correspondence:}

Nataliia Kurdil

03680, Kyiv, Heroiv oborony str., 6

E-mail:kurdil_nv@ukr.net 